\title{
Perancang Ulang Tata Letak Pabrik dengan Membandingkan Metode Grafik dan Computerized Relative Allocation of Facilities Technique (Craft) untuk Meminimasi Ongkos Material Handling di PT. Perindustrian dan Perdagangan Bangkinang
}

\author{
Ekie Gilang Permata ${ }^{1}$, Putri Khartika ${ }^{2}$ \\ ${ }^{1,2}$ Jurusan Teknik Industri, Fakultas Sains dan Teknologi, UIN Sultan Syarif Kasim Riau \\ Jl. HR. Soebrantas No. 155 Simpang Baru, Panam, Pekanbaru, 28293 \\ Email: ekiegilangpermata@uin-suska.ac.id, husniabdurrahmans@yahoo.co.id
}

\begin{abstract}
Abstrak
Tata letak yang baik adalah tata letak yang dapat menangani sistem material handling secara menyeluruh. Sistem material handling yang kurang sistematis menjadi masalah yang cukup besar dan dapat menggangu kelancaran proses produksi. Selain itu juga dapat menyebakan peningkatan biaya yang dikeluarkan dalam perpindahan bahan. PT. Perindustrian dan Perdagangan Bangkinang mengalami permasalahan dalam hal penempatan departemen yang saling berkaitan dalam aliran produksi, yaitu jarak yang terlalu jauh dari satu departemen ke departemen lain, sehingga mengakibatkan besarnya biaya yang dikeluarkan. Perancangan ulang tata letak fasilitas pabrik di PT. Perindustrian dan Perdagangan Bangkinang menggunakan dua metode yaitu metode Grafik dan CRAFT. Tata letak alternatif yang dihasilkan oleh metode grafik dan CRAFT mendapatkan hasil yang lebih baik jika dibandingkan dengan tata letak yang telah diterapkan oleh perusahaan pada saat ini,. Alternatif layout metode grafik merupakan layout usulan yang terpilih karena berdasarkan perhitungan Total jarak, momen perpindahan, dan ongkos material handling $(\mathrm{OMH})$ memiliki nilai terkecil. Jika dibandingkan dengan tata letak sekarang, metode grafik mengurangi ongkos material handling sebesar Rp. 111.022,5,- atau sebesar 40,94\%.
\end{abstract}

Kata Kunci: CRAFT, Grafik, Ongkos Material Handling, Tata Letak.

\section{Latar Belakang}

Tata letak fasilitas pabrik memiliki dampak yang cukup significant terhadap performansi perusahaan seperti ongkos material handling, workin process inventory, lead times, produktivitas, dan performansi pengantaran. Desain fasilitas pabrik yang baik adalah yang mampu meningkatkan keefektifan dan keefisienan melalui penurunan perpindahan jarak material, dan ongkos material handling. Tata letak yang baik adalah tata letak yang dapat menangani system material handling secara menyeluruh. Sistem material handling yang kurang sistematis menjadi masalah yang cukup besar dan menggangu kelancaran proses produksi sehingga mempengaruhi sistem secara keseluruhan (Susetyo, dkk, 2010).

PT. Perindustrian dan Perdagangan Bangkinang merupakan salah satu perusahaan manufaktur yang bergerak dibidang pengolahan karet remah (crumb rubber) yang memproduksi dua jenis produk crumb rubber yaitu SIR 10 dan SIR 20. Ada dua tahap dalam pembuatan produk crumb rubber SIR 10 dan 20 ini yaitu pengolahan I atau proses penggilingan dan pengolahan II atau proses Peremahan. Dalam satu hari PT. P\&P Bangkinang dapat memproduksi produk crumb rubber hingga \pm 55 ton.

Saat ini kondisi layout fasilitas pabrik di PT. P\&P Bangkinang mengalami kendala dalam hal tata letak fasilitas, diantaranya susunan tata letak yang kurang teratur, terdapat aliran pemindahan bahan yang berpotongan (cross movement) yang dapat mengganggu dalam proses produksi dan yang sangat jelas terlihat adalah jarak pemindahan bahan (material handling) antar departemen cukup jauh.

Jarak yang harus ditempuh untuk memindahkan produk akhir yang sudah dikemas didalam forming box ke gudang penyimpanan (warehouse) sangat jauh yaitu sejauh 95,55 m dan harus melewati beberapa departemen seperti lantai produksi pengolahan I, kantor, parkir, gudang bahan baku (storage), dan ruang penjemuran. Begitu juga halnya dengan gulungan blanked yang dihasilkan pada pengolahan I, gulungan blanked ini akan dijemur untuk mengalami proses pengeringan alamiah di kamar jemur. Jarak antara lantai produksi pengolahan I dan kamar jemur juga cukup jauh yaitu $70,35 \mathrm{~m}$, tentu saja hal ini sangat menguras waktu dan tenaga dalam hal perpindahan material yang dapat menyebabkan proses produksi menjadi tidak efektif dan efisien sehingga hal ini 
dapat mengakibatkan besarnya ongkos material handling karena kegiatan dilakukan berulang-ulang.

Hal ini dapat menyebabkan total momen perpindahan yang besar, sehingga dapat meningkatkan biaya material handling dan secara tidak langsung juga meningkatkan beban biaya produksi. Untuk mengatasi permasalahan diatas, maka perlu adanya suatu pertimbangan bagaimana membuat atau mengubah tata letak fasilitas yang ada menjadi lebih efektif dan efisien. Perancangan tata letak pabrik yang baru pada penelitian ini dirancang menggunakan dua metode yaitu metode Grafik dan CRAFT.

Metode Grafik merupakan algoritma heuristik yang dapat memberikan gambaran secara langsung tentang hubungan antar departemen sehingga lebih mudah dimengerti. Penelitian dengan metode ini dilakukan untuk mengurangi total momen perpindahan (massa $\mathrm{x}$ jarak) yang terjadi pada lantai produksi. Dengan adanya pengurangan total momen perpindahan, maka biaya produksi yang ditujukan untuk material handling cost akan berkurang (Budi, dkk, 2014).

CRAFT merupakan sebuah program perbaikan, program ini mencari perancangan optimum dengan melakukan perbaikan tata letak secara bertahap. CRAFT mengevaluasi tata letak dengan cara menukarkan lokasi departemen satu dan lainnya. Perubahan antar departemen diharapkan dapat mengurangi biaya perpindahan material. Selanjutnya CRAFT membuat pertimbangan pertukaran departemen untuk tata letak yang baru, dan ini dilakukan secara berulangulang sampai menghasilkan tata letak yang terbaik dengan mempertimbangkan biaya perpindahan material (Purnomo, 2004).

Penelitian tugas akhir ini bertujuan untuk membuat perbaikan tata letak fasilitas atau perancangan ulang tata letak (re-layout) pada area produksi PT. Perindustrian dan Perdagangan Bangkinang untuk mengoptimalkan aliran material dengan meminimasi ongkos material handling.

\section{Metode Penelitian}

Metodologi penelitian merupakan deskripsi dari seluruh rangkaian kegiatan yang dilaksanakan selama proses penelitian yakni dari awal kegiatan sampai dengan akhir penelitian. Metode ini digunakan untuk mengarahkan serta mempermudah proses pemecahan masalah dan menganalisa hasil pengolahan melalui manajemen penelitian yang baik sehingga penelitian yang dilakukan dapat menjadi lebih berkualitas. Adapun uraian langkahlangkah penelitian tersebut adalah sebagai berikut.

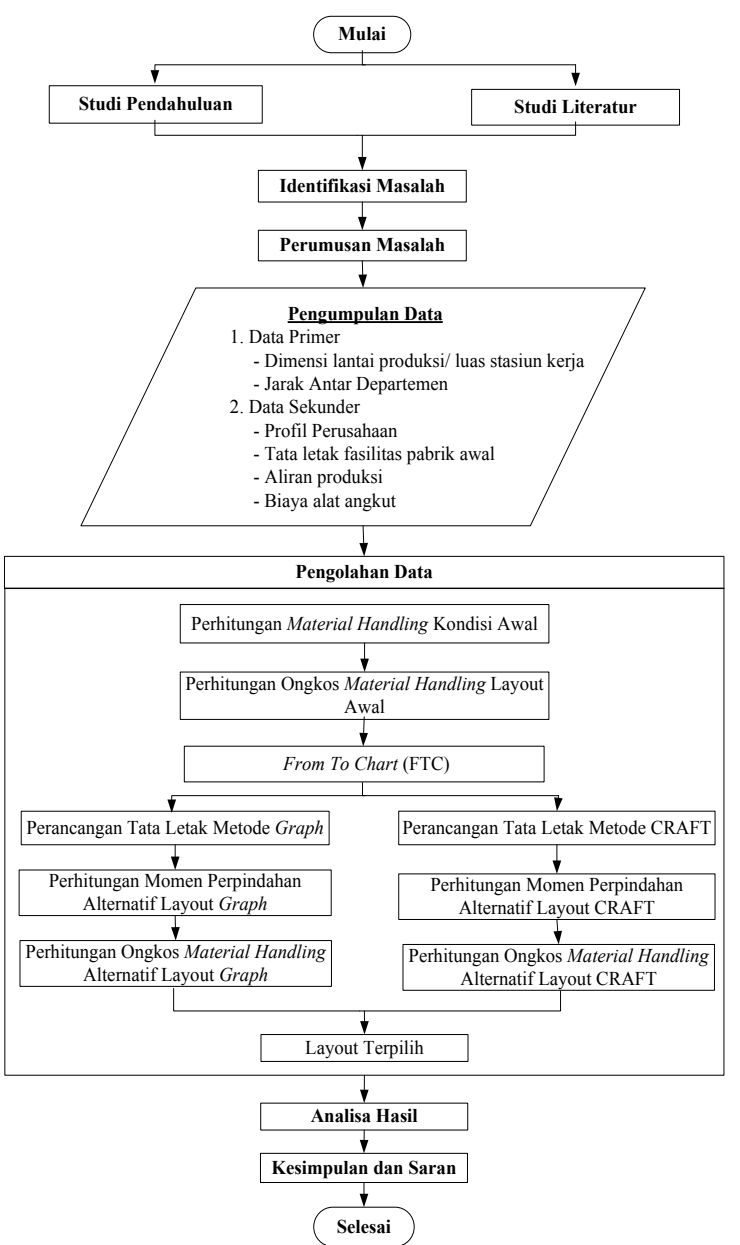

Gambar 1. Metodologi Penelitian

\section{Hasil dan Pembahasan}

\section{Perhitungan Material Handling Kondisi Awal}

Perhitungan kondisi awal dilakukan untuk mengetahui berapa besar jarak perpindahan antar departemen produksi, frekuensi perpindahan material, dan momen perpindahan material di PT. P\&P Bangkinang pada saat ini berdasarkan layout Exiting.

1. Jarak Antar Departemen Produksi

Perhitungan jarak lintasan antar departemen produksi yang ada diukur secara rectilinear dari centroid ke centroid lainnya. Dalam penelitian ini adapun jarak yang dihitung adalah jarak material handling yang dilewati saat proses produksi, yaitu jarak dari storage (1) ke lantai produksi-I (2), lantai produksi-I (2) ke kamar jemur (3), kamar jemur (3) ke lantai produksi-II (4), dan dari lantai produksiII (4) ke warehouse (5). Adapun perhitungannya adalah sebagai berikut: 


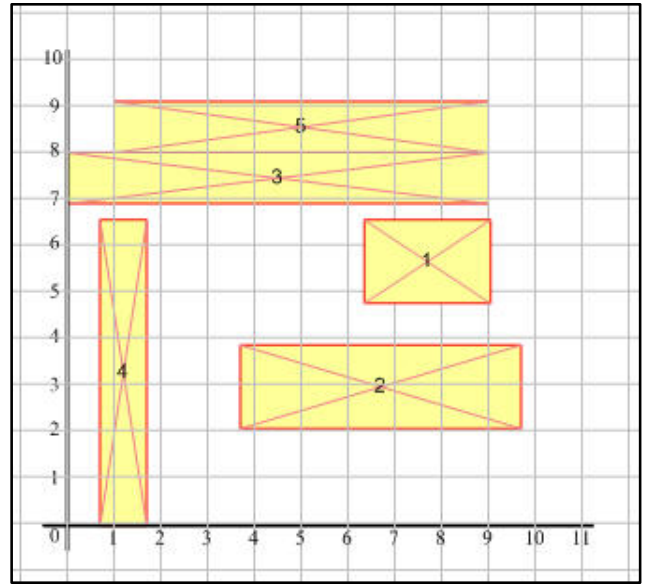

Gambar 2. Block Layout Exiting

Perhitungan jarak menggunakan persamaan dij= $|x i-x j|+|y i-y j|$, maka didapati jarak sebagai berikut:

Tabel 1. Rekapitulasi Data Jarak Antar Departemen Produksi

\begin{tabular}{|c|l|l|c|c|}
\hline No & \multicolumn{1}{|c|}{ Dari } & \multicolumn{1}{c|}{ Ke } & Persamaan & $\begin{array}{c}\text { Jarak } \\
(\mathbf{m})\end{array}$ \\
\hline 1 & Storage & $\begin{array}{l}\text { Lantai } \\
\text { Produksi I }\end{array}$ & 3,7 & 38,85 \\
\hline 2 & $\begin{array}{l}\text { Lantai } \\
\text { Produksi I }\end{array}$ & $\begin{array}{l}\text { Kamar } \\
\text { Jemur }\end{array}$ & 6,7 & 70,35 \\
\hline 3 & $\begin{array}{l}\text { Kamar } \\
\text { Jemur }\end{array}$ & $\begin{array}{l}\text { Lantai } \\
\text { Produksi II }\end{array}$ & 8,8 & 92,4 \\
\hline 4 & $\begin{array}{l}\text { Lantai } \\
\text { Produksi II }\end{array}$ & Warehouse & 9,1 & 95,55 \\
\hline
\end{tabular}

2. Perhitungan Frekuensi Perpindahan

Frekuensi perpindahan dapat diketahui dari jumlah unit yang dipindah dibagi dengan kapasitas dari alat angkut yang digunakan.

Tabel 2. Rekapitulasi Frekuensi Perpindahan

\begin{tabular}{|c|l|l|c|c|}
\hline No & \multicolumn{1}{|c|}{ Dari } & \multicolumn{1}{|c|}{ Ke } & $\begin{array}{c}\text { Material } \\
\text { Handling }\end{array}$ & Frekuensi \\
\hline 1 & Storage & $\begin{array}{l}\text { Lantai } \\
\text { Produksi I }\end{array}$ & Forklift & 170 \\
\hline 2 & $\begin{array}{l}\text { Lantai } \\
\text { Produksi I }\end{array}$ & $\begin{array}{l}\text { Kamar } \\
\text { Jemur }\end{array}$ & $\begin{array}{c}\text { Gerobak } \\
\text { dorong }\end{array}$ & 143 \\
\hline 3 & $\begin{array}{l}\text { Kamar } \\
\text { Jemur }\end{array}$ & $\begin{array}{l}\text { Lantai } \\
\text { Produksi II }\end{array}$ & $\begin{array}{c}\text { Gerobak } \\
\text { dorong }\end{array}$ & 131 \\
\hline 4 & $\begin{array}{l}\text { Lantai } \\
\text { Produksi II }\end{array}$ & Warehouse & Forklift & 40 \\
\hline
\end{tabular}

3. Perhitungan Momen Perpindahan Awal

Momen perpindahan didapat dari hasil perkalian frekuensi perpindahan dengan jarak antar departemen yang berhubungan $\mathrm{Z}_{\mathrm{i}-\mathrm{j}}=\mathrm{f}_{\mathrm{i}-\mathrm{j}} \mathrm{x}$ $d_{i-j}$
Tabel 3. Rekapitulasi Momen Perpindahan

\begin{tabular}{|c|l|l|c|}
\hline No & \multicolumn{1}{|c|}{ Dari } & \multicolumn{1}{c|}{ Ke } & $\begin{array}{c}\text { Momen } \\
\text { Perpindahan (Z) }\end{array}$ \\
\hline 1 & Storage & $\begin{array}{l}\text { Lantai } \\
\text { Produksi I }\end{array}$ & $6.604,5$ \\
\hline 2 & $\begin{array}{l}\text { Lantai } \\
\text { Produksi I }\end{array}$ & $\begin{array}{l}\text { Kamar } \\
\text { Jemur }\end{array}$ & $10.060,05$ \\
\hline 3 & $\begin{array}{l}\text { Kamar } \\
\text { Jemur }\end{array}$ & $\begin{array}{l}\text { Lantai } \\
\text { Produksi II }\end{array}$ & $12.104,4$ \\
\hline 4 & $\begin{array}{l}\text { Lantai } \\
\text { Produksi II }\end{array}$ & Warehouse & 3.822 \\
\hline
\end{tabular}

4. Perhitungan OMH Layout Awal

Ongkos material handling atau biaya yang dikeluarkan oleh perusahaan untuk operasional pemindahan material dipengaruhi oleh ongkos material handling permeter, jarak antar departemen yang berhubungan, dan frekuensi perpindahan yang terjadi. Pada penelitian ini, ongkos material handling yang dihitung adalah biaya operasional forklift yang dikeluarkan oleh perusahaan berupa biaya bahan bakar.

Tabel 4. Rekapitulasi OMH Awal

\begin{tabular}{|c|c|c|c|c|c|}
\hline No & Dari & Ke & $\begin{array}{c}\text { Bahan } \\
\text { Bakar/m }\end{array}$ & $\begin{array}{c}\text { OMH/OMH/ } \\
\text { m }\end{array}$ & $\begin{array}{c}\text { OMari } \\
\text { hare }\end{array}$ \\
\hline 1 & Storage & $\begin{array}{l}\text { Lantai } \\
\text { Produksi I }\end{array}$ & 0,004 & 22,6 & $\begin{array}{c}135 . \\
600\end{array}$ \\
\hline $\begin{array}{l}2 \\
2 \\
\text { Produksi } \\
\text { II }\end{array}$ & Warehouse & 0,006 & 33,9 & $\begin{array}{c}135 . \\
600\end{array}$ \\
\hline \multicolumn{3}{|c|}{ Total } & $\mathbf{0 , 0 1 0}$ & $\mathbf{5 6 , 5}$ & $\begin{array}{c}\mathbf{2 7 1 .} \\
\mathbf{2 0 0}\end{array}$ \\
\hline
\end{tabular}

Berdasarkan tabel diatas maka biaya material handling layout awal adalah Rp 271.200.

\section{Perancangan Tata Letak dengan Metode Grafik}

1. Perhitungan Metode Grafik

Metode grafik merupakan metode perancangan tata letak yang menggunakan grafik kedekatan (adjacency graph) sebagai penghubung antara departemen-departemen atau fasilitas-fasilitas yang ada, dengan tujuan memperoleh bobot terbesar (Hadiguna dan Setiawan, 2008). Langkah-langkah yang dilakukan:

a. Menentukan pemindahan antar 2 departemen yang memiliki momen perpindahan terbesar, yaitu departemen 3 dan 4 dengan momen perpindahan sebesar $12.104,4$.

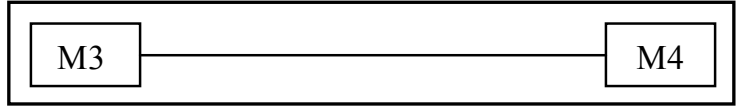

Gambar 3. Grafik Antar Departemen 3 dan 4

b. Menentukan stasiun ke tiga yang akan dimasukkan ke dalam grafik. stasiun ketiga dipilih berdasarkan jumlah momen yang 
terkait dengan dua stasiun yang terpilih dilangkah pertama.

Tabel 5. Iterasi-1

\begin{tabular}{|c|c|c|c|l|}
\hline & M3 & M4 & Total & \\
\hline M1 & 0 & 0 & 0 & \\
\hline M2 & $10.060,05$ & 0 & $10.060,05$ & (Dipilih) \\
\hline M5 & 0 & 3.822 & 3.822 & \\
\hline
\end{tabular}

Gambar 4. Grafik Iterasi-1

c. Cara yang sama dilakukan sampai semua stasiun kerja yang ada telah masuk ke dalam grafik

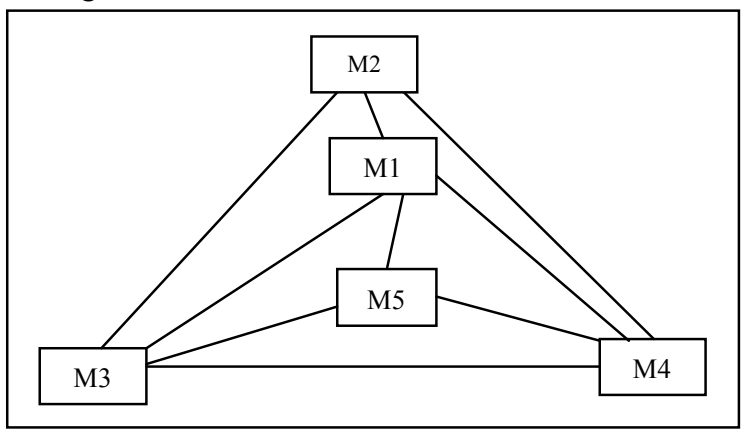

Gambar 5. Hasil Metode Grafik

Setelah semua stasiun telah masuk dalam grafik dapat dilakukan pembuatan rancangan alternatif dari metode grafik Gambar 6 . menyajikan block layout dari rancangan alternatif metode grafik.

2. Perhitungan Jarak Alternatif Layout Metode Grafik

Setelah mendapatkan tata letak usulan alternatif metode grafik, maka dilakukan perhitungan jarak antar departemen berkaitan untuk alternatif layout grafik tersebut. Hasil perhitungan jarak alternatif layout metode grafik dengan perhitungan rectilinear.

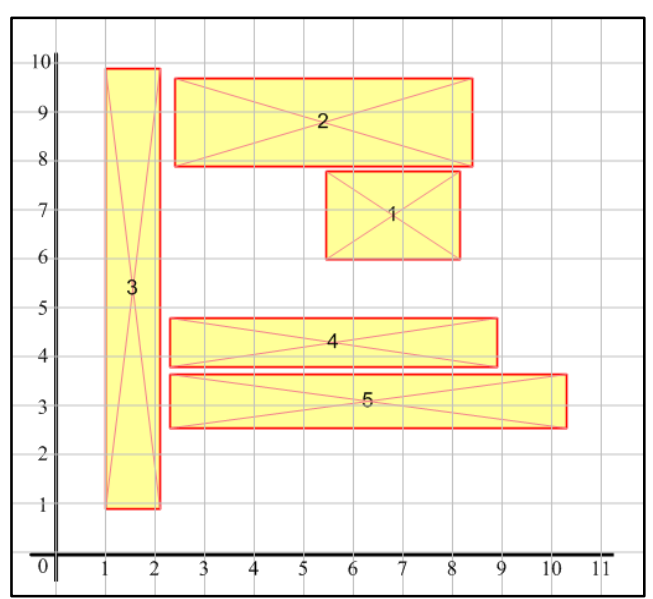

Gambar 6. Block Layout Alternatif Metode Grafik
Tabel 6. Rekapitulasi Data Jarak Layout Alternatif Metode Grafik

\begin{tabular}{|c|l|l|c|c|}
\hline No & \multicolumn{1}{|c|}{ Dari } & \multicolumn{1}{|c|}{ Ke } & Persamaan & $\begin{array}{c}\text { Jarak } \\
\text { (m) }\end{array}$ \\
\hline 1 & Storage & $\begin{array}{l}\text { Lantai } \\
\text { Produksi I }\end{array}$ & 3,3 & 34,65 \\
\hline 2 & $\begin{array}{l}\text { Lantai } \\
\text { Produksi I }\end{array}$ & $\begin{array}{l}\text { Kamar } \\
\text { Jemur }\end{array}$ & 7,2 & 75,6 \\
\hline 3 & $\begin{array}{l}\text { Kamar } \\
\text { Jemur }\end{array}$ & $\begin{array}{l}\text { Lantai } \\
\text { Produksi II }\end{array}$ & 5,1 & 53,55 \\
\hline 4 & $\begin{array}{l}\text { Lantai } \\
\text { Produksi II }\end{array}$ & Warehouse & 1,9 & 19,95 \\
\hline
\end{tabular}

3. Momen Perpindahan Layout Alternatif Metode Grafik

Tabel 7. Rekapitulasi Momen Perpindahan layout Alternatif Metode Grafik

\begin{tabular}{|c|l|l|c|}
\hline No & \multicolumn{1}{|c|}{ Dari } & \multicolumn{1}{c|}{ Ke } & $\begin{array}{c}\text { Momen } \\
\text { Perpindahan (Z) }\end{array}$ \\
\hline 1 & Storage & $\begin{array}{l}\text { Lantai } \\
\text { Produksi I }\end{array}$ & 5890,5 \\
\hline 2 & $\begin{array}{l}\text { Lantai } \\
\text { Produksi I }\end{array}$ & $\begin{array}{l}\text { Kamar } \\
\text { Jemur }\end{array}$ & 10810,8 \\
\hline 3 & $\begin{array}{l}\text { Kamar } \\
\text { Jemur }\end{array}$ & $\begin{array}{l}\text { Lantai } \\
\text { Produksi II }\end{array}$ & 7015,05 \\
\hline 4 & $\begin{array}{l}\text { Lantai } \\
\text { Produksi II }\end{array}$ & Warehouse & 798 \\
\hline
\end{tabular}

4. Ongkos Material Handling Layout Alternatif Metode Grafik

Hasil perhitungan ongkos material handling atau biaya yang dikeluarkan untuk operasional forklift berdasarkan layout alternatif metode grafik dapat dilihat dibawah ini:

Tabel 8. Rekapitulasi Ongkos Material Handling Layout Alternatif Metode Grafik

\begin{tabular}{|c|l|l|c|c|}
\hline No & \multicolumn{1}{|c|}{ Dari } & \multicolumn{1}{|c|}{ Ke } & $\begin{array}{c}\text { Bahan } \\
\text { Bakar/m }\end{array}$ & $\begin{array}{c}\text { OMH/ } \\
\text { hari }\end{array}$ \\
\hline 1 & Storage & $\begin{array}{l}\text { Lantai } \\
\text { Produksi I }\end{array}$ & 0,004 & 133.114 \\
\hline 2 & $\begin{array}{l}\text { Lantai } \\
\text { Produksi II }\end{array}$ & Warehouse & 0,006 & $27.063,5$ \\
\hline
\end{tabular}

Berdasarkan tabel diatas maka biaya material handling layout alternatif untuk metode grafik adalah Rp 160.177,5,-

\section{Perancangan Tata Letak dengan Metode CRAFT}

Perancangan tata letak dengan metode CRAFT pada penelitian ini dibantu dengan menggunakan software Quant System (QS). Adapun data yang digunakan dalam pengolahan ini adalah titik koordinat masing-masing departemen, jarak antar departemen satu departemen ke departemen lainnya, dan penentuan jumlah departemen yang 
fixed atau tidak dapat dipindahkan. Pada penelitian ini tidak terdapat departemen yang tidak dapat dipindahkan.

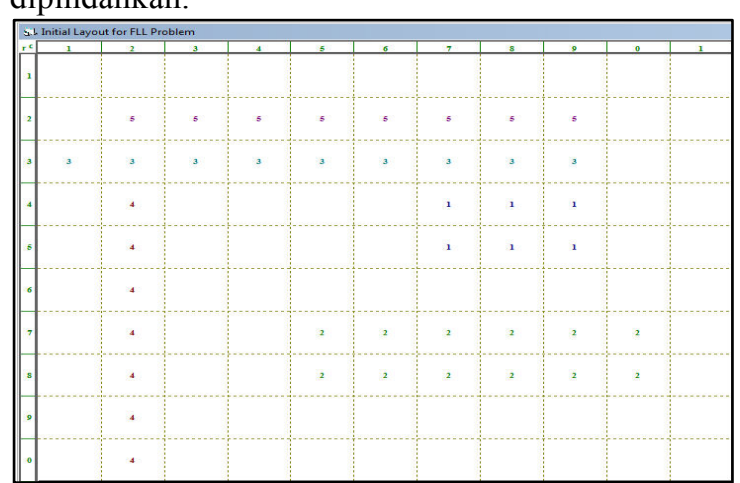

Gambar 7. Block Layout Diagram Awal

Pengolahan metode CRAFT pada penelitian ini menggunakan solution option Improve by Exchanging 2 Departement, jumlah iterasi yang hasilkan software Winqsb 2.0 untuk mencapai hasil paling optimal adalah sejumlah 1 iterasi. Alternatif layout yang diberikan oleh satu iterasi tersebut mengalami perubahan letak pada departemen kamar jemur dan lantai produksi-II.

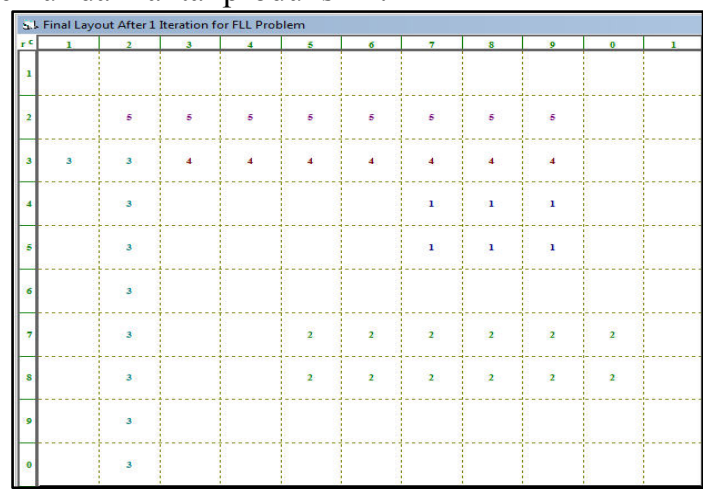

Gambar 8. Alternatif Layout Metode CRAFT

1. Perhitungan Jarak Layout Alternatif Metode CRAFT

Perancangan alternatif layout metode CRAFT dengan bantuan software Winqsb 2.0, selain memunculkan alternatif layout dapat pula memunculkan jarak antar departemen. Gambar 9 menyajikan jarak antar departemen dari alternatif layout CRAFT.

\begin{tabular}{|c|c|c|c|c|c|c|}
\hline $\begin{array}{c}\text { 03-17-2016 } \\
15: 08: 56\end{array}$ & $\begin{array}{c}\text { To } \\
1\end{array}$ & $\begin{array}{c}\text { To } \\
2\end{array}$ & $\begin{array}{c}\text { To } \\
3\end{array}$ & $\begin{array}{c}\text { To } \\
4\end{array}$ & $\begin{array}{c}\text { To } \\
5\end{array}$ & $\begin{array}{c}\text { Sub } \\
\text { Total }\end{array}$ \\
\hline From 1 & $\mathbf{0}$ & $\mathbf{3 , 5 0}$ & 7,72 & 3,50 & 5 & 19,72 \\
\hline From 2 & $\mathbf{3 , 5 0}$ & $\mathbf{0}$ & 7 & $\mathbf{6}$ & 7,50 & 24 \\
\hline From 3 & 7,72 & 7 & 0 & 7,22 & 7,72 & 29,67 \\
\hline From 4 & 3,50 & 6 & 7,22 & 0 & 1,50 & 18,22 \\
\hline From 5 & 5 & 7,50 & 7,72 & 1,50 & 0 & 21,72 \\
\hline Sub-Total & 19,72 & 24 & 29,67 & 18,22 & 21,72 & 113,33 \\
\hline
\end{tabular}

Gambar 4.9 Jarak Alternatif layout CRAFT

Berdasarkan gambar diatas maka jarak antar departemen produksi layout alternatif metode CRAFT adalah sebagai berikut:
Tabel 9. Rekapitulasi Data Jarak Layout Alternatif Metode CRAFT

\begin{tabular}{|c|l|l|c|c|}
\hline No & \multicolumn{1}{|c|}{ Dari } & \multicolumn{1}{c|}{ Ke } & Persamaan & $\begin{array}{c}\text { Jarak } \\
(\mathbf{m})\end{array}$ \\
\hline 1 & Storage & $\begin{array}{l}\text { Lantai } \\
\text { Produksi I }\end{array}$ & 3,5 & 36,75 \\
\hline 2 & $\begin{array}{l}\text { Lantai } \\
\text { Produksi I }\end{array}$ & $\begin{array}{l}\text { Kamar } \\
\text { Jemur }\end{array}$ & 7 & 73,5 \\
\hline 3 & $\begin{array}{l}\text { Kamar } \\
\text { Jemur }\end{array}$ & $\begin{array}{l}\text { Lantai } \\
\text { Produksi II }\end{array}$ & 7,22 & 75,81 \\
\hline 4 & $\begin{array}{l}\text { Lantai } \\
\text { Produksi II }\end{array}$ & Warehouse & 1,5 & 15,75 \\
\hline
\end{tabular}

2. Momen Perpindahan Layout Alternatif Metode CRAFT

Berikut ini hasil perhitungan momen perpindahan dari alternatif layout metode CRAFT.

Tabel 10. Rekapitulasi Momen Perpindahan layout Alternatif Metode CRAFT

\begin{tabular}{|c|l|l|c|}
\hline No & \multicolumn{1}{|c|}{ Dari } & \multicolumn{1}{|c|}{ Ke } & $\begin{array}{c}\text { Momen } \\
\text { Perpindahan (Z) }\end{array}$ \\
\hline 1 & Storage & $\begin{array}{l}\text { Lantai } \\
\text { Produksi I }\end{array}$ & 6247,5 \\
\hline 2 & $\begin{array}{l}\text { Lantai } \\
\text { Produksi I }\end{array}$ & Kamar Jemur & 10510,5 \\
\hline 3 & Kamar Jemur & $\begin{array}{l}\text { Lantai } \\
\text { Produksi II }\end{array}$ & 9931,11 \\
\hline 4 & $\begin{array}{l}\text { Lantai } \\
\text { Produksi II }\end{array}$ & Warehouse & 630 \\
\hline
\end{tabular}

3. Ongkos Material Handling Layout Alternatif Metode CRAFT

Berikut ini merupakan hasil perhitungan $\mathrm{OMH}$ alternatif layout metode CRAFT.

Tabel 11. Rekapitulasi Ongkos Material Handling Layout Alternatif Metode CRAFT

\begin{tabular}{|c|l|l|c|c|}
\hline No & \multicolumn{1}{|c|}{ Dari } & \multicolumn{1}{|c|}{ Ke } & $\begin{array}{c}\text { Bahan } \\
\text { Bakar/m }\end{array}$ & $\begin{array}{c}\text { OMH/ } \\
\text { hari }\end{array}$ \\
\hline 1 & Storage & $\begin{array}{l}\text { Lantai } \\
\text { Produksi I }\end{array}$ & 0,004 & $141.193,5$ \\
\hline 2 & $\begin{array}{l}\text { Lantai } \\
\text { Produksi II }\end{array}$ & Warehouse & 0,006 & 21.357 \\
\hline
\end{tabular}

Berdasarkan pehitungan diatas maka biaya material handling layout alternatif untuk metode CRAFT adalah Rp 162.550,5,-

\section{Layout Terpilih}

Perbandingan jarak, momen perpindahan, dan ongkos material handling layout awal dan alternatif layout metode grafik dan metode CRAFT dapat dilihat pada tabel 4.18 dibawah ini. 
Tabel 12. Perbandingan Jarak, Momen Perpindahan dan $\mathrm{OMH}$

\begin{tabular}{|c|c|c|c|c|c|}
\hline No & $\begin{array}{c}\text { Jenis } \\
\text { Layout }\end{array}$ & $\begin{array}{c}\text { Jarak } \\
(\mathbf{m})\end{array}$ & $\begin{array}{c}\text { Momen } \\
\text { Perpinda- } \\
\text { han/hari }\end{array}$ & $\begin{array}{c}\text { OMH } \\
\text { (Rp) }\end{array}$ & $\begin{array}{c}\text { Pengur- } \\
\text { angan } \\
\text { Jarak }\end{array}$ \\
\hline 1 & $\begin{array}{c}\text { Layout } \\
\text { Awal }\end{array}$ & $\begin{array}{c}297, \\
15\end{array}$ & $\begin{array}{c}32.590,9 \\
5\end{array}$ & $\begin{array}{c}271 . \\
200\end{array}$ & - \\
\hline \multirow{2}{*}{2} & $\begin{array}{c}\text { Alternatif } \\
\text { Layout } \\
\text { Grafik }\end{array}$ & $\begin{array}{c}183, \\
75\end{array}$ & $\begin{array}{c}24.514,3 \\
5\end{array}$ & $\begin{array}{c}160 . \\
177, \\
5\end{array}$ & $\begin{array}{c}40,94 \\
\%\end{array}$ \\
\hline \multirow{3}{*}{3} & $\begin{array}{c}\text { Alternatif } \\
\text { Layout } \\
\text { CRAFT }\end{array}$ & $\begin{array}{c}201, \\
81\end{array}$ & $\begin{array}{c}27.319,1 \\
1\end{array}$ & $\begin{array}{c}162 . \\
550, \\
5\end{array}$ & $\begin{array}{c}40,06 \\
\%\end{array}$ \\
\hline
\end{tabular}

Berdasarkan tabel perbandingan diatas dapat dilihat dari ketiga layout tersebut dapat disimpulkan bahwa layout yang terpilih adalah alternatif layout metode grafik. Hal itu disebabkan karena dari ketiga parameter perbandingan yaitu jarak, momen perpindahan dan ongkos material handling menunjukan bahwa metode grafik memiliki hasil yang paling minimum.

Berikut merupakan perhitungan pengurangan jarak, momen perpindahan dan selisih ongkos material handling dari layout awal dan alternatif layout metode grafik:
a. Selisih Jarak = Jarak Awal - Jarak Perbaikan $=297,15-183,75$
$=113,4$ meter

b. Selisih Momen Perpindahan

$$
\begin{aligned}
= & \text { Momen Awal }- \text { Momen } \\
& \text { Perbaikan } \\
= & 32.590,95-24.514,35 \\
= & 8.076,6 \mathrm{~m} / \text { hari }
\end{aligned}
$$
c. Selisih $\mathrm{OMH}=\mathrm{OMH}$ Layout Awal $-\mathrm{OMH}$ Layout Perbaikan$$
=271.200-160.177,5
$$$$
=\text { Rp. 111.022,5,- }
$$

Berikut ini merupakan perbandingan layout awal dan layout terpilih berdasarkan aliran produksi atau aliran perpindahan material.

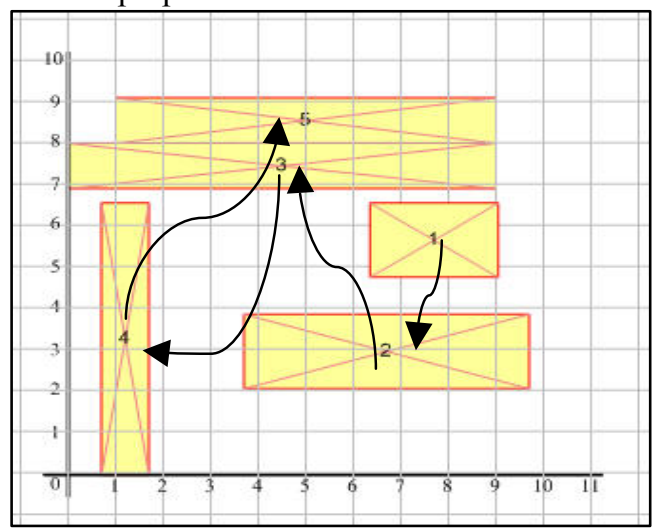

Gambar 10. Aliran Produksi Layout Awal

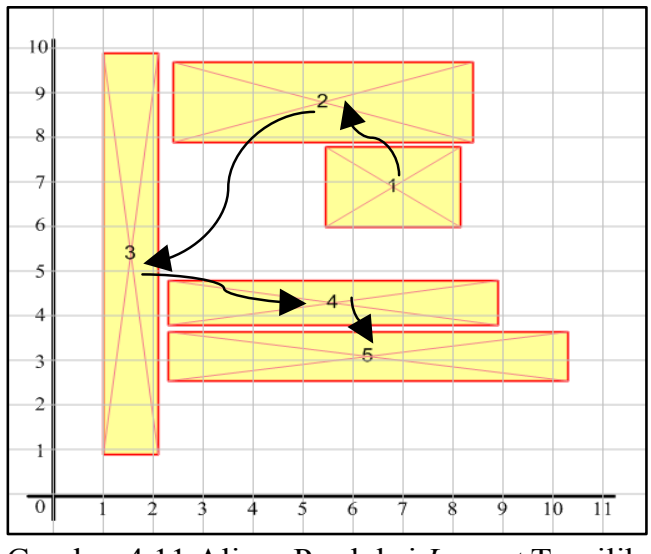

Gambar 4.11 Aliran Produksi Layout Terpilih

\section{Kesimpulan}

Berdasarkan hasil pengolahan data maka kesimpulan yang dapat diambil adalah sebagai berikut:

1. Pembuatan alternatif layout perbaikan untuk area produksi PT. Perindustrian dan Perdagangan Bangkinang menggunakan 2 metode, yaitu grafik dan CRAFT. Alternatif layout metode grafik memberikan perbaikan dengan perubahan letak pada kelima departemen pada area produksi yaitu storage, lantai produksi-I, kamar jemur, lantai produksi-II, dan warehouse. Sedangkan untuk metode CRAFT pengolahan yang dilakukan menggunakan bantuan software Win QSB alternatif layout metode CRAFT menunjukkan perbaikan layout dengan perubahan letak pada 2 departemen, yaitu kamar jemur dan lantai produksi-II.

2. Dari 2 alternatif tata letak baru yang diusulkan, yang memenuhi kriteria ongkos material handling terkecil dan aliran yang optimal adalah tata letak baru usulan alternatif metode grafik. Dengan menggunakan perhitungan menggunakan metode grafik terjadi pengurangan ongkos material handling sebesar Rp. 111.022,5,- atau sebesar 40,94\% dari tata letak awal dan total ongkos material handling paling kecil diantara layout awal dan alternatif layout metode CRAFT.

\section{Saran}

Berikut ini merupakan saran yang dapat menjadi bahan pertimbangan bagi perusahaan dan penelitian selanjutnya:

1. Pihak perusahaan diharapkan dapat menjadikan penelitian ini sebagai bahan pertimbangan kedepannya apabila akan melakukan perubahan tata letak fasilitas pabrik yang sudah ada sekarang. 
2. Diharapkan penelitian selanjutnya dapat menggunakan beberapa ataupun seluruh pendekatan heuristik yang ada sehingga dapat dijadikan sebagai pembanding dari penelitian ini.

\section{Daftar Pustaka}

Apple, J., 1990. Tata Letak Pabrik dan Pemindahan Bahan; edisi ke-3, Institut Teknologi Bandung, Bandung.

Budi, S.E., Mulyono, J., Dewi, D.R.S., 2014. Usulan Perbaikan Tata Letak Pabrik Di PT. A Dengan Metode Graph Theoretic Approach: Jurnal Ilmiah Widya Teknik, 13 (01), 1412-7350.

Hadiguna, R.A., dan Setiawan, H., 2008. Tata Letak Pabrik; Andi, Yogyakarta.

Kristinawati, E., 2000. Perancangan Tata Letak Mesin Dengan Menggunakan Konsep Group Technology Sebagai Upaya Meminimasi Jarak dan Biaya Material Handling: Jurnal Optimum, 01 (01), 71-79.

Ningtyas, Agnes Novita., Choiri, M., dan Azlia, W., 2015. Perancangan Ulang Tata Letak Fasilitas Produksi Dengan Metode Grafik dan CRAFT untuk Meminimasi Ongkos Material Handling: Jurnal Rekayasa dan Manajemen Sistem Industri, Vol. 3 No. 3.

Noviyarsi., Setiawati, L., dan Sandra, D., 2014. Perancangan Tata Letak Fasilitas Produksi Mesin Thresser Untuk Meminimasi Ongkos Material Handling: Jurnal Teknik Industri, Padang.

Pramono, M., dan Widyadana, G.A., 2015. Perbaikan Tata Letak Fasilitas Departemen Sheet Metal 1 PT. MCP: Jurnal Titra, 03 (02), 347-352.

Purnomo, H., 2004. Perencanaan dan Perancangan Fasilitas; Graha Ilmu, Yogyakarta.

Susetyo, J., Simanjuntak, R.A., dan Ramos, J.M., 2010. Perancangan Ulang Tata Letak Fasilitas Produksi Dengan Pendekatan Group Technology dan Algoritma Blocplan untuk Meminimasi Ongkos Material Handling: Jurnal Teknologi, 03 (01), 75-84.

Wahyuni, R.S., dan Safitri, A.A., 2014. Metode Craft Berbantuan Perangkat Lunak WinQsb Untuk Ususlan Perbaikan Tata Letak Fasilitas V2.0 Pada Industri Dompet CV. X: Jurnal Teknologi dan Rekayasa, 19 (03).

Wignjosoebroto, S., 2009. Tata Letak Pabrik Dan Pemindahan Bahan; edisi ke-3, Guna Widya, Surabaya. 